Témoigner

Getuigen
Témoigner. Entre histoire et mémoire

Revue pluridisciplinaire de la Fondation Auschwitz

$118 \mid 2014$

Au nom des victimes. Dictature et terreur d'État en Argentine, Chili et Uruguay

\title{
The Death of Ezequiel Demonty and the End of Human Rights in Argentina
}

La mort d'Ezequiel Demonty et la fin des Droits de l'homme en Argentine

De dood van Ezequiel Demonty en het einde van de mensenrechten in Argentinië

David M. K. Sheinin

\section{Q OpenEdition}

Journals

\section{Electronic version}

URL: https://journals.openedition.org/temoigner/1009

DOI: 10.4000/temoigner.1009

ISSN: 2506-6390

\section{Publisher:}

Éditions du Centre d'études et de documentation Mémoire d'Auschwitz, Éditions Kimé

\section{Printed version}

Date of publication: 1 October 2014

Number of pages: $155-161$

ISBN: 978-2-84174-674-3

ISSN: 2031-4183

\section{Electronic reference}

David M. K. Sheinin, "The Death of Ezequiel Demonty and the End of Human Rights in Argentina", Témoigner. Entre histoire et mémoire [Online], 118 | 2014, Online since 01 October 2015, connection on 03 February 2022. URL: http://journals.openedition.org/temoigner/1009 ; DOI: https://doi.org/ 10.4000/temoigner. 1009 


\section{The Death of Ezequiel Demonty and the End of Human Rights in Argentina}

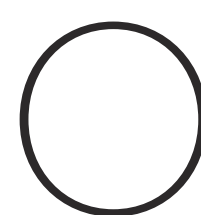

( Ezequiel Demonty and two adolescent friends tumbed out of a dance club in the working class Nueva Pompeya neighbourhood of Buenos Aires. Federal police officers picked them up soon after, tortured them, then forced them into the Riachuelo River, an open sewer into which Ezequiel sank and never reappeared. The case remains both sadly representative of the state of human rights in Argentina, but at the same time unique for its outcome. There have been thousands of Ezequiels since the fall of dictatorship in 1983 - poor Argentines of colour brutalized and in some cases killed by police. However, almost all cases end in impunity for the perpetrators and anonymity for the victims. Demonty's death became an oddity for both the remarkable criminal trials and convictions of nine police officers that followed, and the unprecedented media attention that likely prompted the rare judicial reckoning in the case of police brutality in working class Buenos Aires.

What made Ezequiel Demonty newsworthy? It wasn't the killing itself. Nor was it the well-worn story of ablack working-class young person, beaten by police. What appalled and titilated middle-class television viewers were what seemed sastic dictatorship era hallmarks, horific ghosts from thirty-five years ago. When, for example, it occured to one offer to thow the teenagers into the Riachuelo in a manner reminisent of dictatorhip sadism he was reported to have mock terrified pris "do you know how to swi" The che of

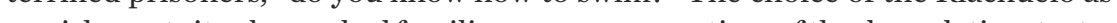
punishment site al so evoked familiar memory narratives of the degradation-torture mix at dictatorship detention centres in the late 1970s.

There is a correlation between justice having been served thanks to an alignment of media pressure, the police convictions, and the framing of the Demonty case as an ugly reminder of the past: dictatorship state terror lives. The correlation also points to a related phenomenon. Human rights in Argenting as politics, culture, and the law remain miredinth law secutions of thuggish military officers from the 1970s. The force and persistence of 
constructed edifice, having remained static, understood almost exclusively through memory making around pre-1984 dictatorship. As a result, the politics of human rights have been largely unresponsive to and distant from the everyday violence experienced by thousands of working class Argentines whose struggles have often had nothing to do with dictatorship, unless one sees Demonty's death in 2002 as a dictatorship legacy in the first instance, twenty years into democracy. At the same time and despite the poor odds for working people, Argentines across class lines have come to understand that to advance claims of rights abuses, to win judicial have come to destand that to advance clains of ights abs to win jucial attention as in the Demonty case, they must invoke dictatorship-era touchstones
on violence and memory.

In this regard, Argentina is exceptional in Latin America for the cultural and political stasis of its dominant rights narratives. Since 1984, no other society has remained so firmly entrenched in decades-old legal and cultural models for how rights violations are addressed, or so politically committed to righting pre-1984 wrongs while focusing so little on the evolution of rights abuses and violence in the present. By contrast, over the past thirty years in each of Colombia, Bolivia, and Guatemala, for example, rights revolutions and fundamental transformations in how society protects those vulnerable to abuse have been at the core of how people have continually rethought citizenship racialidentity, community, the role of the ciety, and the law.

To be sure, there are cases of notable change in Argentina. Twenty years ago, for most, gay marriage was unimaginable. As of 2010 it is the law and is trumpeted in Foreign Relations Ministry press releases as an example of Argentine international human rights leadership. Yet, in this and other cases of progress, victories in Argentina have often touched working people far less frequently than they have white urban middle and upper classes. Trans people (self-identified as travestis) throughout the country, for example, remain the victims of everyday violence and massive workplace discrimination forcing thousands into extreme poverty and the sex trade.

One of many measures of human rights stasis comes in the 2013 Centro de Estudios Legales y Sociales (CELS) report on human rights in Argentina. ${ }^{1}$ A powerful human rights advocacy group, CELS has played a prominent role in shaping the narrative that, in stressing dictatorship-era abuses as the prism through which human rights must be viewed, has helped marginalize decades of emerging human rights problems. Almost 600 pages in length, the volume devotes 130 pages to democratic advances outside Argentina, in Latin America since the end of military rule in the 1970s and 1980s. Meanwhile, a scant six pages is set aside to address rampant abuses of trans people and sex trade workers. Thousands of bits of data appear in book But much of it is only suggestive and opaque. We learn, for example, that the police detain immigrants with greater frequency than long-time residents. But there is no information on what becomes of the former in custody (CELS 2013, 179).

Much of the CELS report falls into two broad categories. Since 1983, governments at all levels have passed thousands of legislative bills and opened hundreds

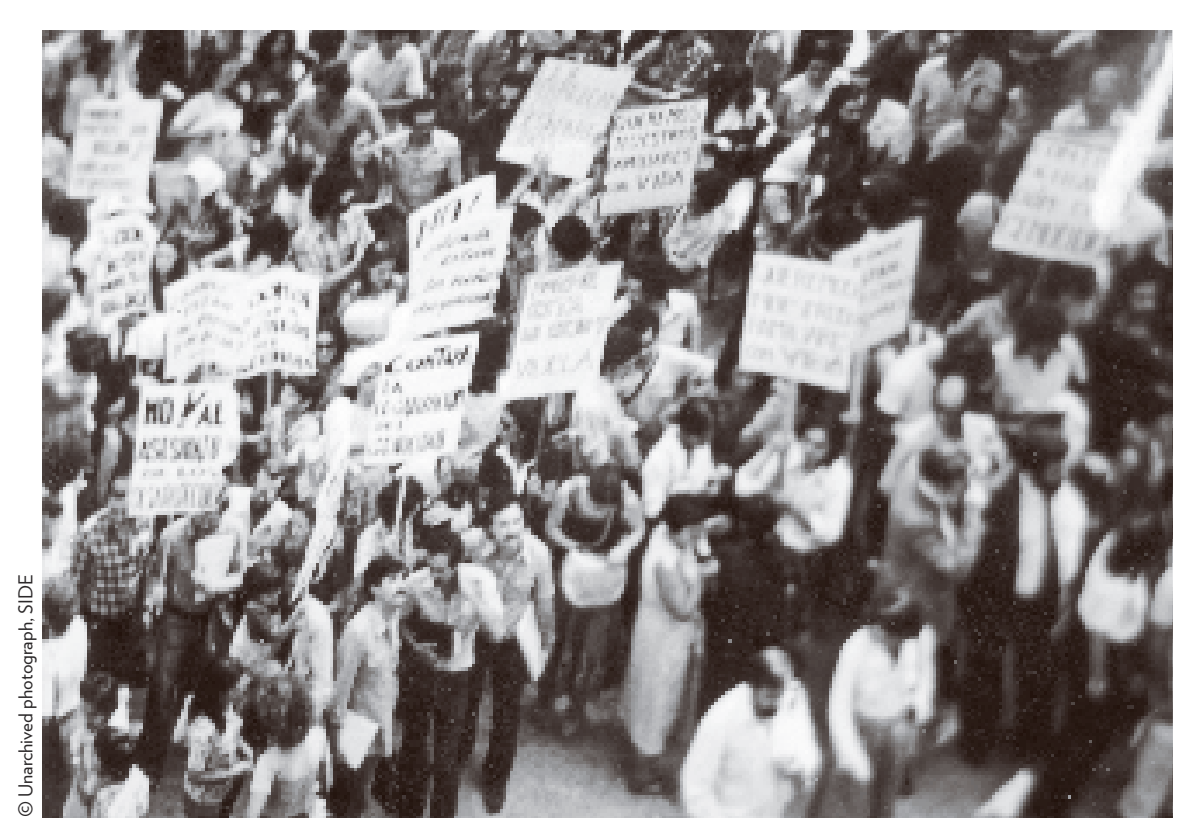

- This photograph of protesters against the was shot by the Secretari (SIDE) in 1978 from window in the Argentin Embassy in Madrid.

of bureaucratic departments to protect human rights. The 2013 CELS report charts these developments. In addition, it reports on a variety of rights-related problems while presenting and summarizing data, often generated by government human rights bureaucracies and as a function of rights-related legislation. Yet, despite the massive data as togy. CELS pronotes the post-dictorship success narative that bureaucracies and legislated change came into place to improve human rights and to ensure that dictatorship would never return to Argentina. But that latter achievement, not the specifics of the former (in hundreds of urban neighbourhoods like that of Ezequiel Demonty), defines success. The report, then, is largely a formal catalogue of legislated and bureaucratic accomplishment with little attention to how new laws work and the plight of those whose rights are most at risk, like marginal youth of colour and trans people.

CELS reports on the December 2013 Buenos Aires Province law providing for just ccess to housing for all residents as an "important instrument for the protection c the to hou "toin the rignment "to intervene incases of deficientliving conditions" (CELS 2013,287). But is there a human rights accomplishmenthered laws and decrees promulgated in the past two decades across Argentina that have benefited a few, but have not stopped the exponential growth of massive, dangerous urban and suburban slums like those in the greater Buenos Aires Longchamps municipality where tens of thousands of Argentines, Paraguayans, and Bolivians live in one-room wooden shacks with minimal indoor plumbing and unreliable, illegal electricity feeds.

In regard to the 2011 landmark federal Mental Health Law, the report notes that for the United Nations, the legislation reflected successful deinstitutionalization strategies for the mentally ill as a global model for human rights. "Once again," CELS boasts, "Argentina is a pioneer in the passage of legislation highlighting fun- 
damental rights derived from international agreements" (CELS 2013, 435). At the same time, the report notes that the legislation is promising but insufficient - an understatement of epic proportions in light of the ongoing dismal funding of state mental health facilities, their associated emptying, and the accompanying surge in the homeless mentally ill.

Two additional cases highlight the long shadow of dictatorship over human rights inertia and their limited relevance as a political, social, and legal set of organizin principles revant to victim of violence. They are the conviction imprisonment princiconment of Ricardo Miguel Cavallo (a.k.a. "Sérpico") in 2011 and the nature of human rights

\section{SÉRPICO AND THE ONGOING PROSECUTION}

$$
\text { OF DICTATORSHIP REPRESSORS }
$$

In December 1983, Raúl Alfonsín won the Argentine presidency ushering in the post-dictatorship period on his reputation as a human rights lawyer. He tied his governance project to the promotion of human rights at home and abroad, and immediately set in place the National Commission on the Disappearance of Persons, the first ever Truth Commission. The lightning-fast, stumning prosecution Thesution

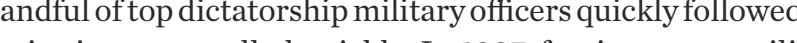
These promising beginnings unravelled quickly. In 1987, fearing a new military intervention, the Alfonsín government passed the Due Obedience and Final Point laws, absolving most officers and soldiers of dictatorship crimes and setting in place an early date after which new prosecutions of senior officers would no longer be permitted. In 1990, President Carlos Menem pardoned the senior officers originally convicted for dictatorship crimes. But the failed promise of human rights under Alfonsín rests less in the unraveling of a judicially strong prosecution and conviction process for human rights violators than in two related judicial tendencies. The judiciary has not so much failed in the prosecution of dictatorship rights violators as it has consumed in fits and starts, endless hours and resour on those violato as in those ( many Argentines feel could go on through 2025 at problems remain unaddressed.

The case of Ricardo Miguel Cavallo is representative of the painfully slow, inefficient, and expensive dedication of the Argentine judiciary to incarcerating dictatorship-era rights violators. It's not that Cavallo did not merit prosecution and conviction. He did. However, the failure of the justice system to track, arrest, prosecute, and convict Sérpico and hundreds of others for almost twenty years after the fall of the dictatorship is typical of judicial inefficiency, and worse, has helped shape an ongoing political, cultural, and financial focus among government, the media and other institutions that organizes how human rights should be und the media, and onderstood around an inter system ha that of Ezequiel Demonty comes to light not in a context of rights and police violence in 2002, but twisted into some sort of grim appendage to a dictatorship that ended two decades earlier.

A naval officer during the military junta, Cavallo oversaw the torture, kidnapping, and murder of hundreds. Though his crimes were documented in the Truth Commission report and many of his victims identified him as a perpetrator in the $1980 \mathrm{~s}$ he retired quietly at the rank of lieutenant commander and went to live in Mexico. In September 2000, the Spanish federal judge Baltasar Garzón sought his extradition and in 2003 Mexican authorities sent him to Spain to face genocide and terrorism charges. In December 2006 the National Court of Spain ruled that Cavallo should

Cave sentenced him to life in prison. In a prosecutorial system that depends entirely on federal judges deciding which cases to pursue, Argentina's focus on human rightsrelated prosecutions remains fixed in time on hundreds of "high profile" cases like that of Cavallo while current and recent rights abuses are rarely prosecuted.

THE CROMAÑÓN FIRE AS HUMAN RIGHTS ABUSE

Argentines have learned that, in the context of the powerful post-dictatorship A ren rights narrative the most likely way toachice any sort ofjudicial reckoning hum framing criminality a a hum is by franing It is no concidilies of the victims of the stillbombing, it was by exactly the same amount that families of the dictatorship disappeared had received. In the courts, in the media, and in public policy, criminality is often codified through a prism of dictatorship era human rights violations.

In 2004, a fire at the Cromañón nightclub in Buenos Aires killed 194 people. With little confidence in the judiciary, family members of the victims formed at least twenty-two human rights organizations as registered cooperatives to fight for justice in regard to who was responsible for the tragedy. They include Articulación de Grupos de Familiares, Cambiar a Esta Realidad, and Memoria y Justicia por nuestros Pibes. These and other groups organized their petitions and protests in teeping with the These and o Car dictatorship-era human rights aeshetic. For Memoriay Justiciapornuestros Pibes, 
to a touchstone language reference to the dominant human rights narratives - the search for "Memory and Justice". The human rights activist Alfredo Grande (Liga Argentina por Derechos del Hombre) starts with the reasonable assertion that, in the first instance, the Cromañón fire is about profit and plunder. Club owners in collusion with corrupt municipal inspectors ignored expensive safety regulations that made escape from the blaze impossible. But the problem is immediately framed as a human rights violation with specific reference to the dictatorship. The triumph of profit and plunder, according to Grande, derives from dictatorship-era priorities orp and abuses of the public. He asserts that their presence in post-1983 Argentina is a legacy of dictatorship human rights abuses. While intriguing, like the Demonty case, the dictatorship human rights abuse legacy is plausible, but not at all clear. More important, it obscures more than it illuminates in each of these cases.

The president of the Asociación por el Esclarecimiento de la Masacre Impune de Ia AMIA, Laura Ginsburg, points to the strategic politics of framing a 2004 crime a a dictatorship-focused human rights issue. Nothing can be expected, she argues, of the failed judicial system or the state. In that context, a stylized human rights protest becomes the most likely avenue toward results. Such protests by Cromañón human rights groups included multiple "escraches", pro-human rights street protests that originated in the 1980s against rs. Ginsburg calls the Cromañón a "massacre" in keeping with dictatorship killings in the late 1970s and as a continuity of the state terrorism of the military dictatorship.

\section{WINNERS AND LOSERS}

In April 2011, members of the Qom first nation from northern Argentina began a protest encampment on the 9 de Julio Avenue in downtown Buenos Aires. Frustrated by years of failed appeals to provincial and federal authorities on land and resources claims, the group arrived in Buenos Aires in the hope of getting something done. On arrival, they had no sense of how to press for judicial and political results. Very quickly and like the Cromañón protesters in a different legal context, they figured quickly, and like the Crom they figured out making case on tradtona land claims in reference to persistent narratives on dictatorship and human rights, forming strategic political alliances with the Mothers of the Plaza de Mayo and othe media-savvy human rights organizations. A brief media sensation in part for the oddity of an indigenous group camped out in the city, their leader became a wellknown personality and managed an interview with the Pope.

Comparing the outcomes of the Cromañón and the Qom protests brings us back to Ezequiel Demonty. While human rights-based protest and argument, framed by an ambiguous dictatorship legacy, has become the surest way to achieve ajudicial reckoning in Arsentin there are no guarantees. In fact, widely ranging results underline (a) class urban Argentines and have been generally insensitive to working Argentines.

While Cromañón human rights organizations won a rare and important victory in the impeachment of the mayor of Buenos Aires, the Qom people accomplished nothing of substance in regard to their claims. Primed by families of the victims of the fire, through the human rights organizations they formed, an Impeachment Commission formed by the Buenos Aires City legislature dismissed Aníbal Ibarra as mayor, holding him accountable for lax government supervision of nightclub safety and a poor rescue operation. It was an astonishing and unique moment of accountability for the state. Ibarra's guilt or innocence aside, arguments that swayed the Commission drew directly on the hum the hur and others linking the Cromanon massacre to dictatorship state terror, with Ibarra

By contrast, the Qom protest failed. After four months camped out in downtown Buenos Aires, group members quietly left one day for their homes in Formosa province. The Qom could not sustain themselves indefinitely in Buenos Aires. They left with no resolution of their land claims The two cases reflect the correlation between class, whiteness, and blackness in Argentina and human rights-based protest as a mediator of those divides in Argentine society. Like many working people who organize in an effort to press the justice and political systems for change, the Oom people - without the resources to hire lawyers to press their case or to sustain a protest that might last years - were un to budge the legal system. By contrat, the largely white, $\mathrm{m}$ the largely wite, mide class families of the Cromanon more effective at developing strategies of human rights protest for the long term. The human rights groups they founded, for example, weremore effective at gaining access to influential bureaucrats and politicians. They developed strategies for long-term survival, including means of self-support that reflected greater familiarity than the Qom with their urban environment. One Cromañón protest organized a print shop to support itself, while another farmed and sold vegetables. Their greater ability to generate income and negotiate complex legal networks allowed the Cromañón groups to press successfully for the Ibarra prosecution, and to remain active for a decade, continuing still to press for new prosecu mother (but not other mothers of young victims of police violence) a home in a better neighborhood. She refused. Dolores Sigampa occasionally appears in the media offering advice to other mothers who have lost adolescents to police violence in impoverished, drug-infested neighborhoods. In 2012, in reference to one such case, she stated simply that she came to visit a grieving mother, because she continues to sympathize with poor young people victimized by police violence. Sigampa doesn't filter her language through the dominant human rights story. She remains mired in grinding urban poverty, and in 2011 told reporters about her son Emanuel who, after the death of Ezequiel, sank into drug addiction, crime, and despondency. Somebody had told her that Emanuel was eligible for government-supported treatment by the terms of the new Mental Health Law She needed ajudicialorder, though, ant the terms of the new Mental Heath Law. She needed ajudcial order, though, and a psychiatric reportonher
Bibliography

- Abal Medina, Paula \& Nicolás
Menéndez (eds) Procesos de Menéndez (eds.) Procesos de Argentina reciente, Buenos Aires Imago Mundi, 2001

- Centro de Estudios Legales y
Sociales (CELS), Derechos humanos en Argentina. Informe
2013, Buenos Aires: Siglo XX1. 2013.

- Ciancaglini, Sergio, Nicolás
Pousthomis, Lucas D'Amore \& Graciela Daleo, Generación Resistencia, socididaridad y rocant Buenos Aires: Lavaca, 2005.

- Nejamkis, Lucila \& Jorge Alvarez Nievas, 'Migración y Cernacional de Historíia Polititic dica $4,2012,445-63$.

- Rodríguez, Estéban,
Mariana Relli \& Gabrie Melli \& Gabriel Appella Manual de derechos humanos para Colectivo de lnvestis, La P $\mathrm{P}$ Colectivo de Investigación y
Acción Jurídica/Galpón Sur, Rozengardt, Diego (ed.);
Pensar Cromañón, Buenos Aires: Castiglioni, 2008.

- Soledad Montero, Ana, iY al
final un día volvimos' Los usos de la memoria en el discusososos de kirchnerista (2003-2007), Buenos

- Soria, Claudia, Paola Cortés
Rocca \& Edgardo Dieleke (eds.), Politicas del sentimiento: El peronismoy la construcción
de la Argentina moderna, Buenos eo, 2010

- Sutton, Barbara, 'Contesting
Racism: Democratic Citizenship, Human Rights, and Antiracist Politics in Argentiná, Latin American Perspectives $35(6)$ 